\title{
Surfaces
}

\section{ROCK MUSIC AND NATIONAL IDENTITY IN HUNGARY}

\section{Kathryn Milun}

Volume 1, 1991

URI : https://id.erudit.org/iderudit/1065258ar

DOI : https://doi.org/10.7202/1065258ar

Aller au sommaire du numéro

Éditeur(s)

Les Presses de l’Université de Montréal

ISSN

1188-2492 (imprimé)

1200-5320 (numérique)

Découvrir la revue

Citer cet article

Milun, K. (1991). ROCK MUSIC AND NATIONAL IDENTITY IN HUNGARY.

Surfaces, 1. https://doi.org/10.7202/1065258ar
Résumé de l'article

Marxisme et nationalisme. La forme et la signification du discours d'identité nationale en Hongrie tel qu'il apparait dans la culture populaire. Rock hongrois et « shamanpunk ». Le débat autour du drapeau national. 


\title{
ROCK MUSIC AND
}

\section{NATIONAL IDENTITY IN HUNGARY}

Kathryn Milun[*]

\begin{abstract}
Marxism and nationalism. The political form and meaning of the discourse of national identity in Hungary as it appears in popular culture. Hungarian rock and shamanpunk. The debate over the national flag.
\end{abstract}

\section{RÉSUMÉ}

Marxisme et nationalisme. La forme et la signification du discours d'identité nationale en Hongrie tel qu'il apparait dans la culture populaire. Rock hongrois et "shamanpunk". Le débat autour du drapeau national.

It is not surprising that the collapse of the Soviet empire in Eastern Europe has released the repressed conflicts of the "nationalities" question. The problem of national identity was utterly neglected by Marxist-Leninist social theory[1] which in reducing political forms of power to property relations, understood class as the fundamental category for investigating social conflict. Of course, and this point has been belabored by many contemporary 
social theorists, the labor of bourgeois society is not only divided by property relations but by a variety of social identities: gender and race, to name a few, but also national identity, an issue that has particular pertinence in the ethnically diverse area once subsumed under Soviet dominance.

This categorical omission in Marxist theory has serious epistomological and methodological implications. While there may have been some legitimacy to the claim that an objective science (i.e. political economy) was sufficient to study property relations and the flows of capital, there is no objective science that can claim to account for the ways in which tradition, social roles and codes of

\section{/pp 5-6/}

behavior operate and undergo transformation in historical individuals. What is needed, I submit, is a more hermeneutically-based semiotic approach that will allow us to produce maps of social change.

Unlike previous methodogies in the social sciences which aim at producing an account of the social totality, this paper's semiotic attempt to map "national consciousness" in postcommunist Hungary will instead locate sites where conflicts between the nation and the state intersect. There is certainly a global dimension to the resurgent nationalism in Hungary--like many countries, Hungary is also reacting to the collapse of empire, the large scale migration of labor, and the global territorializing power of capitalism, all of which are indeed remapping the world. However the shape of the debates around "Hungarianness" are molded by the particular configuration of the state in Hungary ([until very recently] a socialist bureaucracy) together with the historical traditions that both preceded that state formation and were produced by it. Thus the resurgence of anti-modern traditions next to the liberal institutions characteristic of modernity, as well as postmodern uses of the premodern, figure into the debates over Hungarian identity and serve, in a comparative framework, as interesting instances of the ways in which nationalism is currently resurgent.

I begin with the nature of the state in Hungary. East German author Rudolf Bahro's book The Alternative in Eastern Europe, published in the late seventies, gives a thorough analysis of the state in the countries of actually existing socialism. Although Hungarian political philosophers disagree over Bahro's conclusions[2], they enthusiastically agree with his description of the social organization of the socialist bureaucratic state which, while trying to bridge the 
separation of civil society and the state that is characteristic of modernity, in fact produced a specific kind of what Bahro calls "surplus consciousness."[3] Unlike the ideology of the self that developed in (Western European) countries where the liberal state claimed to be protecting the distinction between the private and the public person so essential to the social totality known as "bourgeois society," in the countries of actually existing socialism the state busied itself with setting up party representatives and organizations in every aspect of social life. Surplus consciousness is the result of the state's failure to territorialize the entire social realm.[4] The important point here is that for Hungarians, surplus consciousness--a term I want to substitute for the problematic notion of a general Hungarian national consciousness--is the understanding of Hungarian identity as it is worked out in relation to the Hungarian experience of some forty years of oppression by the political/ juridical bureaucratic institutions of the socialist state. It is the experience of resistances, contradictions, and ambiguities specific to the history of contemporary Hungarians, an experience that is now being articulated in the recent debates over what a non-communist Hungary will be like.

I want to chart these debates in two kinds of discursive formations. First, I will look at the debates surrounding the symbol to be placed on the new Hungarian flag. These discussions are /pp 7-8/ generated from the "official discourse"--thus marking a relatively closed space for debating Hungarian identity--of post-communist Hungarian politics (beginning in March of 1990). Generally, the debates range from claims common to the liberal political sphere of modernity and those which are decidely anti-modern. Secondly, I will look at the debates on Hungarianness generated in popular, specifically rock culture. This is a site overdetermined by the surplus consciousness I refered to earlier. Thus, as we shall see, it cannot simply be called "unofficial" culture. Moreover, given the relative openness of the field of popular culture, we have access to more experimentation and play with notions of identity. Here, as I try to show, Hungarians are involved in a decidely postmodern contestation over national identity.

In the summer and early autumn of 1990, Hungarians carried out a fascinating public debate over the symbol to be placed in the hole in the nation's flag left by the excision of the hammer and sickle.[5] The discussion turned around whether or not Hungary would once again fly the image of the crown of King Stephen, Hungary's first Christian King, on their coat of arms. Coming from a country whose leaders recently tried to pass a constitutional amendment to have the American flag treated as a magical extension of the actual country rather than as a symbol, I found the debate in Hungary rather enlightened. But for some Hungarians the return of the crown--it was finally affixed to the flag--reinforced a frightening conservatism: the crown had been reinstated on the flags that followed the defeat of the revolutions of 1848 (against the /pp 8-9/ 
dominantion of the Austrian monarchy) and 1919 (after the attempt to establish a Communist state in the collapse of the Austro-Hungarian monarchy); thus it was seen by many to be a sign of monarchic as opposed to republican, anti-modern as opposed to modern-liberal sentiments.[6]

The crown, however, is not simply a conservative symbol for Hungarians. Understanding something of the history of the crown allows us to see how it becomes a symbol produced by resistance struggles characteristic of the "surplus consciousness" of which I spoke earlier. When the government of Hungary was taken over by the Communist Party shortly after WWII, King Stephen's crown was smuggled out of the country by loyalists and brought to the United States. It remained there, in Cleveland I believe--the home of some one million Hungarians--until 1979 when it was returned to Budapest by Secretary of State Vance against the objections of those[7] who believed that this symbol of the legitmate, christian state should not be handed over to the the current wrongful, indeed atheist rulers. Thus the crown came to symbolize Hungarian resistance to the communist state.

So, affixed to the flag, the crown enters official culture and becomes the symbol of the state. But not just any state. Since the crown is linked to the beginnings of a Christian Hungary, its new-found legitimacy on the national flag resacralizes the state and, unfortunately, plays into the widespread antisemitism cropping up throughout the region, a prejudice which the socialist state only addressed with great ambivalence. This ugly tradition can now circulate in mainstream culture. For example, one prominent member of the leading conservative party, the well-respected

/pp 9-10/

novelist and poet Sandor Csoori, a longtime proponent of Hungarian populism[8] , appeared on state television last fall explaining why Hungarian Jews had no place in the new Christian Hungary. After generations of hometraining in spotting the contradictions of communism on their T.V. screens, it probably did not escape many television viewers that the film which followed Mr. Csoori's speech was Woody Allen's "Annie Hall" in which Mr. Allen gives a speech on what it means to be Jewish in America.[9] As one young viewer explained to me, "In that film WoodyAllen gave a small speech about what it means to be Jewish in America and how he simply accepts it as a part of everyday life. That speech was probably incomprehensible for a Hungarian." Thus Christianity, in the realm of unoffical culture, could function as a mode of resistance to the state; Christianity as offical culture, on the other hand, becomes a tool of oppression.

Now we turn to the discussion of Hungarian identity in the more open field of popular culture. In both the East and the West, the relation between rock 
music and nationalist sentiments is complicated. Rock music in Hungary, as elsewhere, can function both as a form of oppositional culture and as a support to official, /pp 10-11/ state interests. Signifiers of nationalism in Hungarian rock, however, are historically complicated due to what I've refered to as "surplus consciousness." To examine how this works, we will first look at one of the most popular groups in mainstream Hungarian rock history, Illés, and their rock opera "King Stephen.". We will then look at a very interesting and long standing marginal group, Vágtázó Hállottkémek (The Galloping Coroners) the creators of "shamanpunk."

Illés was the first group to write and sing rock music in the Hungarian language back in the mid 60's. Their politically coded songs[10], relied on the poetic model of the Hungarian folk-music tradition, a tradition every Hungarian schoolchild, urban or rural, learned thanks to the state's interest in maintaining a "folk" notion of Hungarian identity. Before focussing on their 1984 rock opera King Stephen, it is important to understand how Illés is a product of the very specific twist that Western rock culture took in the countries of East/Central Europe in the sixities.

Before Illés, Hungarian radio played predominantly the English "beat" sounds as well as local Beatle imitators. As Illés grew in popularity, the State, which of course owned the record production industry as well as most of the venues for the public circulation of music, eventually warmed to the group, but its policy toward specifically Hungarian rock music was often contradictory. Through the 50's and early sixties, offical state discourse considered rock to be propaganda of Western capitalism. (Indeed, Voice of America was using its jazz and rhythm and blues broadcasts as propaganda throughout this period. For the Cold War American /pp 11-12/

programmers, as well, rock music had instrumental value.[11] ). Up until the mid-sixties, the state's record industry and radio stations focussed on Hungarian folk music and "serious music." (Well into the eighties, Hungary's cultural publications for foreign consumption avoid the achievements of Hungarian rock musicians while focussing ad nauseam on things like, "Liszt's Influence on Bartok Reconsidered".)

With the popularity of Illés and other groups in the mid-sixties, the state began organizing to control youthful energy. Youth centers, factories, and universities opened clubs where Hungarian bands could play as long as they obtained a permit. To get a permit, a band had to know a set number of foreign songs and dance songs.[12] This was one way of regulating who could play in public places. As the State began to sanction rock music, Hungarian youth /pp 12-13/ was put in a contradictory position. As one intense, rock-literate teenager told me in the mid-eighties, "Illés was good until they started making a lot of albums. That's the problem. There are a lot 
of really interesting groups, and I like them until they become popular. Then they sell out. Their music isn't political anymore."[13] While this may sound Adornoesque, it is important to note that while "selling out" in the West is associated with commodification, in Hungary "selling out" did not necessarily refer to a commodity relation but rather to an affiliation with state.

How did unofficial music circulate, then, without the help of the technological means of reproduction in the hands of the state? Curiously enough, the radio stations were relatively autonomous from the recording industry [since the early 1980s]. Groups who were not allowed to cut albums could nevertheless gain access to radio air-time by recording a local gig and then having the tape played, usually on Sunday morning rock shows. Kids could circumvent state policy regarding the distribution of unsanctioned groups by recording off the radio onto cassettes and circulating this homerecorded music in "samizdat" form.[14] This process /pp 13-14/ is the opposite of the more or less economically determined pop culture of the West; in the surreptitous economy of Hungarian rock music, it was culture that determined the distribution of the music; culture, one might say, that determined the economic flow.

Now back to Illés. One of the major events of Hungarian rock history in the 80 's was the appearance of the rock opera Istvan Kiraly ("King Stephen") written by the two lead members of Illés. The performance, which played to sold out audiences in Budapest and the provinces (it finally became a movie), tells the story of the founder of the Hungarian state, the newly baptized Stephen and his fight with Koppány, the pagan chief of the remaining non-christian tribe of Hungarians. The opera is based on Hungarian political history: back in the eleventh century, Stephen was caught in a delicate political situation. The orthodox church had converted the tribes to the east and pagan Stephen, needing to consolidate his power, accepts christianity and kills off his enemy Koppány whose bodily organs are then cut out and sent to unchristianized regions of Hungary to help convert the reluctant. Stephen gains sainthood and becomes the patriarchal symbol of the Hungarian nation, while Koppány has his bowels redistributed.

At the end of the rock opera which, in its open-air performances[15] was a spectacular event complete with live horses and fireworks, a Hungarian flag (without communist insignia) is raised and the national anthem played. There are reports of adults in the audience weeping over the finale. Those who criticised the play for being too nationalistic were, in turn, attacked by a public.that would not be reprimanded for sentiments that undeniably stemmed from what I have been terming the Hungarian "surplus consciousness." /pp 14-15/ 
Certainly, back in 1984 when King Stephen hit the stage there was nothing to foretell the shape of the nationalism and the fall of the communist party that was to come in 1990. In fact, 1984 was also the year when Hungary first faltered in its foreign debt payments to the West. The country was in a severe economic crisis and First Secretary Kádár was attempting to impose new economic and political restraints and to recentralize power that had been redistributed during the previous four years of liberal economic policies, policies that had allowed, for the first time, the privatization of small businesses. Some people claimed that the sudden popularity of King Stephen brought on by the rock opera played right into the government strategy to reinforce a strong centralized state. And yet there is no doubt that the allegory of the Magyar King overpowering his "atheist" enemy also spoke to the surplus consciousness of the majority of Hungarians whose sentiments vis à vis their own history had been so twisted by the state. Thus, rock culture had produced an overdetermined sign in King Stephen: even in mainstream culture, the rock opera could be read as both an attempt to reassert a sacralized state in opposition to official communist doctrine and as a means of supporting the socialist state in its new bid for recentralization.

I might add that when Illés held a major come-back concert last year in Budapest's largest stadium it was attended by 80,000 fans, making it the second largest concert in Hungarian history [16] , The following week Illés' concert was televised throughout Hungary and to all the neighboring countries where Hungarian is spoken. (Hungarians living in the neighboring countries of Eastern Europe number close to three million: around two million in Romania, 620,000 in Czechoslovakia, 420,000 in Yugoslavia, 170,000 in the Soviet Union.[17] ) Only Romania, /pp 15-16/where Hungarians make up the largest ethnic minority in Europe, refused to broadcast the concert. You may recall the reports of ethnic violence coming from this region in the spring of 1990, disputes between ethnic Hungarians and Romanians in the area of what was formerly Hungary. Given its realm of eager Magyar rock afficionados, one might say that Hungarian rock music has created another map of the region.[18]

\section{A Shaman's Headdress for the Hungarian Flag}

Another interesting use of specifically Hungarian history in rock culture during this period comes from a band created on rock's punk margins. This band is called Vágtázó HallotKémek, the Galloping Coroners, a name which signifies the group's dynamic task of examining the dead of their society. The Galloping Coroners perform what they call "shamanpunk," a fascinating hybrid of traditional, pre-christian Hungarian folk culture and the Western genre of industrial music that first surfaced from the bowels of West 
European and American megatropolis. Vágtázó Hallot Kémek has been around since 1978. The group's leader and main theoretician, Attila Grandpierre is an astronomer currently employed by the Hungarian Mathemetics Institute. Two other band members are physicists.[19] They are the only group to emerge from Hungary's dynamic punk scene of the early eighties./pp 16-17/

To begin my analysis of shamanpunk, I take the description of the band and its music provided by the sociologist, Anna Szemere--the only Hungarian speaking analyst of the Hungarian rock scene I know of who is writing in English. Although the passage is long, I encourage you to be attentive to the metaphors employed in the desciption provided by this social scientist.

The [Galloping] Cororners' live shows are literally cultic rituals, aimed at releasing the psychosomatic energies of the subconscious. Many of the fans, skinhead-looking 'hard' punks and young bohemians, are ready to participate actively in the event with agitated body movements, shouts and screams as suggested by the dynamics of the musical process. Occasionally, there is also a visual emphasis on simulated tribal rituals with costumes, make-up and hair styles which can include raw meat and bunches of grass attached to T-shirts or birds' feathers covering the skin all over.

The music creates a completely self-contained and closed acoustic space, the illusion of a trip in time and space, into

an environment where nothing reminds the listener of everyday realities and concerns. An apparently chaotic but carefully constructed soundscape is produced by the vocals, guitars and an array of drums, tympani and other, non-conventional percussion. Excessive amplification, fuzz and echo are heavily relied on to produce a thick noise. The typical concert is made up of just a few longer musical units bearing no title and following one another without pause. The whole process of the performance stimulates as well as acts out ecstasy. (Szemere, 1989: 185)

As someone trained in literary theory, I find this description to be more like a description coming from modernist aesthetics than from scientific social theory. Instead of contextualizing the Galloping Coroners' work, as I will soon do, as part of the struggle to define Hungarian national identity, Szemere treats it as a self-contained, exotic scene of extatic play-acting. Her only explicit attempt to interpret Shamanpunk and it practitioners is the following reductionist psychologization: "It is tempting to attribute [Grandpierre's] ideas to the punk's general obsession with (or craving for) a charismatic figure, a superstar, a hero, a leader. No doubt a great deal of nostalgia is attached to reviving this prehistoric tradition." 
Unable to see any further significance to the shamanpunksters' use of their pre-christian history outside of obsessive hero worship, Szemere sells the band short. In what follows, I hope to show that the band has created a powerful counter-hegemonic practice by using a form of Hungary's premodern, pagan past to counteract not only the powerful antimodern sentiments of mainstream Hungarian nationalism centered around the legacy of a monarchical, Christian Hungarian state but also to challenge the state's co-optation of "folk" music. In this respect I see shamanpunk as a specifically postmodern cultural form. It is a hybrid formation created to experience a new form of subjectivity.

The following description of shamanpunk comes from a 1984 article by the band's leader Attila Grandpierre entitled: "Punk's Connection to Shaman Music as a Folk Music: The Mechanical Effect of Art's Magical Powers"[20]. The obvious reference to Walter Benjamin's famous essay "The Work of Art in the Age of its Mechanical Reproduction" is telling. Grandpierre appears to be deconstructing Benjamin's (and most modernists') assumption that authentic art is devalued in the act of its being mechanically reproduced. Grandpierre seems to be reversing the terms and saying that the authentic (i.e. folk music) can be experienced as a mechanical effect, i.e. it has an iterative quality which in no way diminishes its "magical effects," or its "aura" as Walter Benjamin would call it.

Grandpierre relates the iterative quality and function of shamanpunk music to the role music formerly played in, as he says, "prehistoric times." "Totem music, the music of the shaman rituals functioned for its creators as a magical power capable of leading to ecstasy."[21]

And ecstasy for Grandpierre is "the highest degree of consciousness." Ecstasy is an experience of the self produced--almost mechanically--through the strong rhythmic experience of shaman music. It opens up the modern experience of the self as a historical subject since rhythm is the experience of time outside the linear temporality of history. And this experience of time, Grandpierre is claiming, is not restricted to the historical past of the ancient magyars; it is accessible to hungarians today in the experience of ecstasy.

Grandpierre furthermore relies on the work of a number of famous Hungarian anthropologists[22] who wrote

on the traditional shamanic practices retained in Hungarian folk beliefs. But Grandpierre dismisses the academic interpretive framework which in his opinion keeps these texts lifeless. After quoting a shaman's song cited by one of this century's most prolific Hungarian anthropologists, Grandpierre 
tells the reader, "Now let's decode [the chant] by first getting rid of the traditional method of ethnographic writing ....In the professional writing," he continues, "the being summoned by the shaman is thought to be a supernatural power, a spirit" (p. 91)..He then criticises this interpretation by reference to existing pagan folk customs (descriptions of which tend to resemble the shamanpunk concerts). Grandpierre seeks to demonstrate that the shaman does not call on powers beyond himself but more exactly on powers that he himself possesses: with the imperative call of his chant, "the shaman's text magically comes true and transforms him [the shaman]. By speaking the text and performing the actions marked in the text, the shaman heightens his own dispostional, emotional readiness "(p. 92)

The participatory nature of shamanpunk concerts bear out this performative element of Grandpierre's new interpretation of shaman power as a force that is internal to, embodied in human beings.[23] Departing from the ethnographers' practice of transforming Hungarian shamanic traditions into academic texts, Grandpierre insists on revitalizing them. For shamanpunks, the texts are no longer mere objects to be studied; they must be liberated from the discourse that disempowered them and reread as animated traces capable of leading to experiences of ecstasy. In other words, writing is not an effect but rather a cause. You describe it and then it happens. Like Foucault's inversion of Marx where culture comes before the economic realm, Grandpierre is similarly inverting the base and superstructure model, placing representation and writing in the position of performatives.

But of course in this model writing must be translated into the experience of ecstasy, the immediate and almost "mechanical" product of which is a new experience of the self, a new subject position. This "authentic" appropriation of "folk" music must still be understood within the dynamic of surplus consciousness, in my opinion. It stands in relation to the state's use of folk culture in Hungary and the subjectivity which such official culture allows. Grandpierre is ruthless in describing the disempowering affect of official music on Hungarians today. "Serious music," Grandpierre says, "which sticks to the strict, life inhibiting rules of harmonics and the twelvetone system is not capable of creating a new culture." Both classical and contemporary music "expect the audience's pregiven consent and forebearance. There are no participants here, just performers and listeners... Fake 'folk music', beyond its commercial uses is only good for damaging the word 'folk' and for frightening as many people as possible away from true 'folk music' Let's add to this the sleep inducing hits of light/ pop music and we can say that the overwhelming part of today's music is quite simply only good for exposing man to his own misery and for manipulating him so that he can be even more manipulable. The music that used to be so vigorous and alive that neither man nor animal could free himself from its magical power is now a disemboweled mammoth on tiptoes."[24] Here the Galloping Coroner's theoretician waxes Adornoesque. 
Now, I just want to add that contextualizing shamanpunk as a movement of the surplus consciousness that arises out of the experience of the socialist state's attempt to appropriate folk music in Eastern Europe distinguishes this movement from the Western ressurgence of shamanic traditions in trends of what is called in the United States "New Age" culture. The uses of shamanism in the West are not in and of themselves counterhegemonic. (Note the example of Polish Presidential candidate Timinski who claimed that his dark journey into the the jungles of Peru and subsequent shamanic instruction by the indigenous peoples he encountered there was instrumental to his becoming a millionaire. Timinski was offering his shamanic-based economic expertise as a self-made millionaire to the Polish voters as evidence of his ability to bring Poland out of her financial nightmare.)

To a certain extent then, an ironic reading of shamanpunk is in order. Grandpierre refers to the music of the ancient Magyars as "A régi, szuverén népzene/ the ancient, sovereign folk music." Furthermore, he reminds his readers that "the shaman's headdress [is] the precursor to the crown..." (p. 96) In the nationalistic game of authentic "Hungarianness, " the Galloping Coroners might be said to have outsmarted the Christian nationalists for whom the rock opera "King Stephen" had such great appeal: they remind audiences that it is the animist and not the christian heritage which is more "deeply" Hungarian.

Here I must explain that I am assuming the position of a Kierkegaardian ironist for whom the superior term, in this case the shamanic tradition, becomes neither the true story--an essentialist reading--nor merely one ruse among many by which a nationalist discourse may be tripped up--a reading partaking of what Kierkegaard would call "vacuous infinity"[25] and what we might call bad postmodernist theorizing. Although a shaman's headress for the Hungarian flag may not be a bad idea, I don't believe Grandpierre is claiming that Hungary's shamanic traditions are more authentically Hungarian than its christian ones. Shamanpunk does not appear to posit nationalist identity as an historical essence (either shamanic or christian). Shamanpunk is not even interested in the basically aesthetic construction of a (Hungarian) nation; its interests lie in

making the experience of [prehistoric] music "the first step in the direction of practical action, "[26] a practical means of experiencing selfempowerment and becoming aware of the somnambulent affect of institutionalized music--whether it be "serious," pop or folk--in Hungary today.

To sum up then, the signs of "Hungarianness" (i.e. the crown of St. Stephen or Magyar shamanic traditions) that we see in Hungarian rock culture are 
neither conservative nor liberatory in and of themselves. The same symbol may be appropriated for official or counter-hegemonic ends. The crown, we recall, represented Hungary's attempted resistance to Soviet domination. But once it was affixed to the flag, once it was linked to the state, it took on a conservative, even anti-modern meaning. Likewise Grandpierre's use of Hungary's shamanic past as part of a new pragmatic approach to subject production differs enormously from the state's museumified use of Hungarian folk culture. Shamanpunk's hybrid notion of "authentic" folk music seeks to offer a new form of self-experience for Hungarian youths, a subject position that offers them some relief from being a subject of the state.

\title{
Rice University , Dept. of Anthropology
}

\author{
Houston - TX 77251 - USA
}

Surface Page d'Acceuil/Home Page

[*] I wish to thank Zoltan Vajda for his assistance. Also, Nancy Armstrong, George Lipsitz and Csaba Toth gave helpful comments after reading an earlier version of the manuscript.

[1] Many postmarxist social theorists say that the failure of MarxistLeninism as an adequate response to the problems of a capitalist world order was made clear in 1914 when workers broke from offical internationalist policy and realigned themselves along nation-state lines. See Vajda, The State and Socialism (St. Martin's Press, New York) 1981 and Laclou and Mouffe, Socialist Strategy and Hegemony (Verso: London), 1985.

[2] See Ference Fehér, Agnes Heller Eastern West, Western Left: Totalitarianism, Freedom and Democracy (Humanties Press Internation, Inc., Atlantic Highlands, New Jersey) 1987 p. 21-22. Also Vajda, The State and Socialism pp. 107-108.

[3] Bahro is comparing state formations in East and Western Europe where the bourgeosie was formed in opposition to the feudal relations established by the monarchical state. The situation of the state in the U.S. is historically different and would need to be analyzed as well.

[4] By "territorialize" I mean bring all the values and meanings in a particular scope under the sway of one axiomatic. This is Deleuze's term for 
the way in which capitalism devalues a resistant social formation, and then revalues it according to the axioms of capital. (See Deleuze and Guattri The Anti-Oedipus (...))

[5] This official symbol of communism was first cut out of the Hungarian flag by dissenters during the Hungarian uprising of 1956. After 1956, the hammer and sickle did not reappear on the offical state flag as a concession to the events of '56. But in the fall of 1989, the history of the symbol's absence was recalled by Hungarians who took to the streets waving the revolutionary flag of 1956: the tricolored Hungarian standard with a huge hole cut out of its center.

[6] This is how the Hungarian philosopher Mihály Vajda described the debate. (Personal interview, Oct. 1990).

[7] This was, for the most part, the view of the large Hungarian immigrant community in the United States.

[8] Csoori's populism must be understood in the context of the post-WWI break-up of Eastern Europe when Hungarian-speakers suddenly found themselves in the newly created states of Yugoslavia, Czechislovakia and especially Romania (there are around two million Hungarians in Transylvania). Criticism of the harsh treatment of Hungarians at the hands of the ethnic majorities in Romania, for example, was ideologically problematic in Communist Hungary because it aroused reformist, nationalist sympathies which ran counter to the dominant internationalist orthodoxy. Csoori's outspoken writings and activities on behalf of ethnic Hungarians won him a certain heroic support during this period.

[9] György Szabo, program organizer at Petöfi Csarnok, the largest youth center in Budapest; interview, Oct. 1990.

\section{[10] See "Sárga Rozsa".}

[11] Free albums from Voice of America were available to many East Europeans who had the courage to send in for them. I know of at least one Hungarian with a very fine jazz collection all obtained through Voice of America. They also sent avant-guard periodicals like Evergreen.

[12] This information is taken from a personal interview in 1986 with István Hevessy, organizer of the Amateur State Rock Competitions who works at Almássy Téri Szabadidö Központ/ Almássy Square Freetime Center in Budapest. Hevessy noted that of all the amateur arts in Hungary, rock music is the most popular but the least supported by the state. He figured that about $50 \%$ were playing hard rock, $25 \%$ new-wave and punk, 5-10\% jazzrock and 5\% avant-guard. See also, János Sebök, Magyarrock vol I and II (Budapest, Zenemükiadó) 1984, the first and only history of Hungarian rock music; and Anna Szemere, "Some Institutional Aspects of Pop and Rock in Hungary" in Popular Music vol. 3 (1987) pp.121-142. For an hilarious demonstration of the state's attempt to organize early rock energies see Gyula Gazdag's documentary film "A válogatás/ The Selection" (Béla Balázs Studios) 1970. 
[13] Interview with Hungarian youth attending national amateur rock competition in June, 1986.

[14] Apparently the police knew of and monitored such broadcasts. One Hungarian I spoke to said that he and his friends used to amuse themselves reading about these gigs and broadcasts in an official journal put out by and for the Hungarian police. One can imagine the description of these rock groups by state surveillance agencies. According to my informant, the police knew about the groups, but didn't know what to do about them other than simply spy on them. It is also worth noting that these independent musicians were often (and somewhat paradoxically) supported by clubs which were organized with funds from the Communist Youth Club. The collapse of the Communist Party system and consequent loss of funds is one factor in the current lack of forums for new groups to find an audience. (Interview with György Szabo from the Petöfi Csarna Youth Center, Budapest (October, 1990).

[15] "Istvan Kiraly" also ran at the National Theater of Budapest.

[16] The first being Louis Armstrong's appearance in 1968 which sold 100,000 seats.

[17] These figures are from Pál Zsigmond Pach, "A nemzettudatról napjainkban /On National Consciousness in our Time" 1986 in Társadalmi Szemle (the theoretical journal of the Hungarian Socialist Workers Party). A review of the article appears in English in New Hungarian Quarterly \#103, Autumn 1986 pp 166-170.

[18] I am certainly not suggesting that Hungarian rock music necessarily creates an unproblematic or internationalist map of the region. To Slovenians, to take the example of one repressed minority, Hungarian broadcasts may recall not simply the days of the Hapsburg empire but the spector of Hungarian nationalism.

[19] The group's background, then, is not the art-school enviroment as is the case with another well known group from this period, Bizottság, whose leader is an artist living in the Szentendre "art colony" just outside of Budapest. The members of another very popular punk group, Beatrice, were from working-class background. Although the group, which has since disbanded, was unable to record in the its hey-day of the early eighties (they had something like samiszdat recordings circulated from recordings of their concert appearances) a Hungarian record company has just put out their first album of this year. The album is called "Nostalgia '80: Songs of Our Childhood;" nostalgia for a time when an oppositional group looked and sounded like one? Beatrice's leader, Fero Nagy, now has his own radio program called garage band music. His is clearly a voice that would not have been heard before the party relinquished control of the Hungarian air waves.

[20] "A Punkrock Összefüggesei a Sámám-zenével Mint Népzenével: A Müvészet Magikus Eröinek Hatásmechanikmusa," (1984) in Jó Világ (Good World) ed. Beke and Szöke, Böicsész Index, Budapest, Elte Btk pp. 91-97. 
(All translations from the Hungarian are my own.). Jó Világ, launched in 1984, is an avant guard publication of Hungary's largest University, ELTE. In it artists, musicans of the post-punk era and culture critics suggest that a 'new mentality' is on the rise in Hungary to counter act the 'depressed' and 'decadent' official culture. (See Szemere 1989.) Szemere ends her article on Hungarian avant guard with a quote from Jó Világ: "As the editor László Beke stated, artists working in the spirit of a new optimism 'are producing a 'good world' day by day, at times with hard efforts...constantly reiterating such values as beauty, goodness, friendship, love, dynamic yet intimate human community..." (Jó Világ p. 136) .

[21] Ibid p. 91 "Ecstasy," in Grandpierre's thinking, is similar to Georges Bataille's use of ecstasy as an individual experience of the transgression of limits. This exorbitant experience produces, for Grandpierre too, something like the sovereign subject: (quoting from Grandpierre)...[in the experience of ecstasy,]... "the self...moves from the realm of subordination ...(the pressures of the material world, the unconquerable limits of time and space) to that of independence (sovereignty)....Thus ecstasy makes possible the experience of intimate unity with an embodiment of the forces of nature...In experiencing the harmony of a boundless sensate world, we find companions for our most personal feelings. We recognize that we live together in an undiscovered common fate."

[22] Grandpierre quotes texts collected in Vilmos Diószegi's A sámámhit emlékei a magyar népi müveltségben, 1958 (Remnants of Shaman Belief in Hungarian Folklore). Diószegi also wrote A pogány magyarok hitvilága, 1967 (The Belief World of the Pagan Hungarian), Sámámiszmus 1962 (On Shamanism), and Tracing the Shamans in Siberia--the Story of an Ethnographic Expedition (Oosterhout: Anthropological Publications 1968)

[23] See Szemere's description above. See also Sandor Bódy's 1984 film, "A Kútyai éj dala/Night Song of A Dog" and Lydia Gyarmithy's 1985 film (whose title I forget) both of which have footage of these bands performing.

[24] Grandpierre, p. 96.

[25] See Soren Kieregaard, The Concept of Irony trans. Lee M. Capel (Bloomington, Indiana University Press) 1968 (p. 341).

[26] A a totemzene, a sámánszertartások zenéje alkotói, létrehívói számára valóságosan müködö, müködésben levö varázserö, amely elvezet az extázishoz, és erejével jelképes rendbe foglalja a résztvevö önmaghoz és a világhoz való viszonyát, ezzel megteszi az elsö lépést a gyakorlati cselekvés felé. (91). 